\title{
Urban Pond Water Contamination in India
}

\author{
Ankit Yadav, Pravin Kumar Sahu, Suryakant Chakradhari, Keshaw Prakash Rajhans, \\ Shobhana Ramteke, Nohar Singh Dahariya, Gaurav Agnihotri, Khageshwar Singh Patel* \\ School of Studies in Chemistry/Environmental Science, Pt. Ravishankar Shukla University, Raipur, India \\ Email: "patelks_55@hotmail.com
}

Received 27 November 2015; accepted 8 January 2016; published 11 January 2016

Copyright (C) 2016 by authors and Scientific Research Publishing Inc.

This work is licensed under the Creative Commons Attribution International License (CC BY).

http://creativecommons.org/licenses/by/4.0/

c) (i) Open Access

\begin{abstract}
The stagnant water reservoirs in urban area of India are severely contaminated with surfactant and microbe due to anthropogenic activities. In this work, water quality of pond water of the most industrialized city: Raipur, CG, India is described. The concentration of surfactant in the term of sodium lauryl sulfate (SLS) in water $(n=16)$ is ranged from $7.0-27 \mathrm{mg} / \mathrm{L}$ with mean value of $17 \pm$ $3 \mathrm{mg} / \mathrm{L}$. All ponds are found to be contaminated with microbes i.e. bacteria, algae and fungi at elevated levels. The physico-chemical characteristics of the pond water are discussed.
\end{abstract}

\section{Keywords}

Surfactant, Water Quality, Microbe, Pond

\section{Introduction}

Pond is stagnant water reservoir used for various purposes i.e. bathing, drinking and washing for humans and other animals. The contaminants i.e. surfactants, microbes, nutrients, heavy metals, organic toxicants, etc. are brought to the pond by the streams, runoff water, municipal waste, etc. [1]-[3]. The water contaminants (i.e. facial coliforms, facial streptococci, Salmonella, algae and fungi) and surfactants cause health hazards [4]-[6]. Many animals that live in the surrounding area, such as migrating birds, and nearby plants depend on these ponds for a rich source of nutrients and water. However, the stagnant water bodies such as ponds, lakes and rivers are contaminated with the microbes and surfactants at hazardous levels [7]-[25]. In this work, the water quality of ponds of Raipur city with emphasis on microbial and surfactant contamination is assessed.

\section{Materials and Methods}

\subsection{Area of Study}

Raipur $\left(22^{\circ} 33^{\prime} \mathrm{N}\right.$ to $21^{\circ} 14^{\prime} \mathrm{N}$ and $82^{\circ} 6^{\prime} \mathrm{E}$ to $\left.81^{\circ} 38^{\prime} \mathrm{E}\right)$ is a capital of Chhattisgarh state, India with population of 2 "Corresponding author.

How to cite this paper: Yadav, A., Sahu, P.K., Chakradhari, S., Rajhans, K.P., Ramteke, S., Dahariya, N.S., Agnihotri, G. and Patel, K.S. (2016) Urban Pond Water Contamination in India. Journal of Environmental Protection, 7, 52-59.

http://dx.doi.org/10.4236/jep.2016.71005 
million. Several ponds $>20$ occurs over $\approx 1000 \mathrm{~km}^{2}$ area in the city for drinking, bathing, washing and fishing purposes. All pond waters are eutrophied with the decreased aquatic biodiversity. They recharge the groundwater resources by transporting the contaminants.

\subsection{Sample Collection}

The water from 16 ponds during April 2014 was sampled, Figure 1. The composite water sample $(100 \mathrm{~mL})$ from five points of each pond was collected into sterile glass bottles $(500 \mathrm{~mL})$ as prescribed in the literature [26]. The physical parameters i.e. pH, temperature (T), electrical conductivity (EC), dissolved oxygen (DO) and reduction potential (RP) were measured at the spot.

\subsection{Analysis}

The water samples were filtered with glass micro filter of pore size, $2 \mu \mathrm{m}$. The total dissolved solid (TDS) value of the sample was determined by evaporation method [26]. The total hardness (TH) and total alkalinity (TA) values were analyzed by the titration methods [27]. The anionic surfactant concentration in the term of sodium lauryl sulfate (SLS) was determined by the flow injection spectrophotometric method [28]. The fluoride content of the water was analyzed by the ion selective method using Metrohm-781 ion meter using the total ionic strength adjustment buffer (TISAB) in the 1:1 ratio. The concentration of ions was analyzed by the Dionex-1100 ion chromatography. The iron content of the water was monitored by the GBC flame AAS-932AA. The sodium adsorption ratio (SAR) and sodium hazard (SH) indices were calculated by using following equations.

$$
\begin{gathered}
\mathrm{SAR}=\left[\mathrm{Na}^{+}\right] / \sqrt{\left\{\left(\left[\mathrm{Ca}^{2+}\right]+\left[\mathrm{Mg}^{2+}\right]\right) / 2\right\}} \\
\mathrm{SH}=(\{[\mathrm{Na}]+[\mathrm{K}]\} /\{[\mathrm{Na}]+[\mathrm{K}]+[\mathrm{Mg}]+[\mathrm{Ca}]\}) \times 100
\end{gathered}
$$

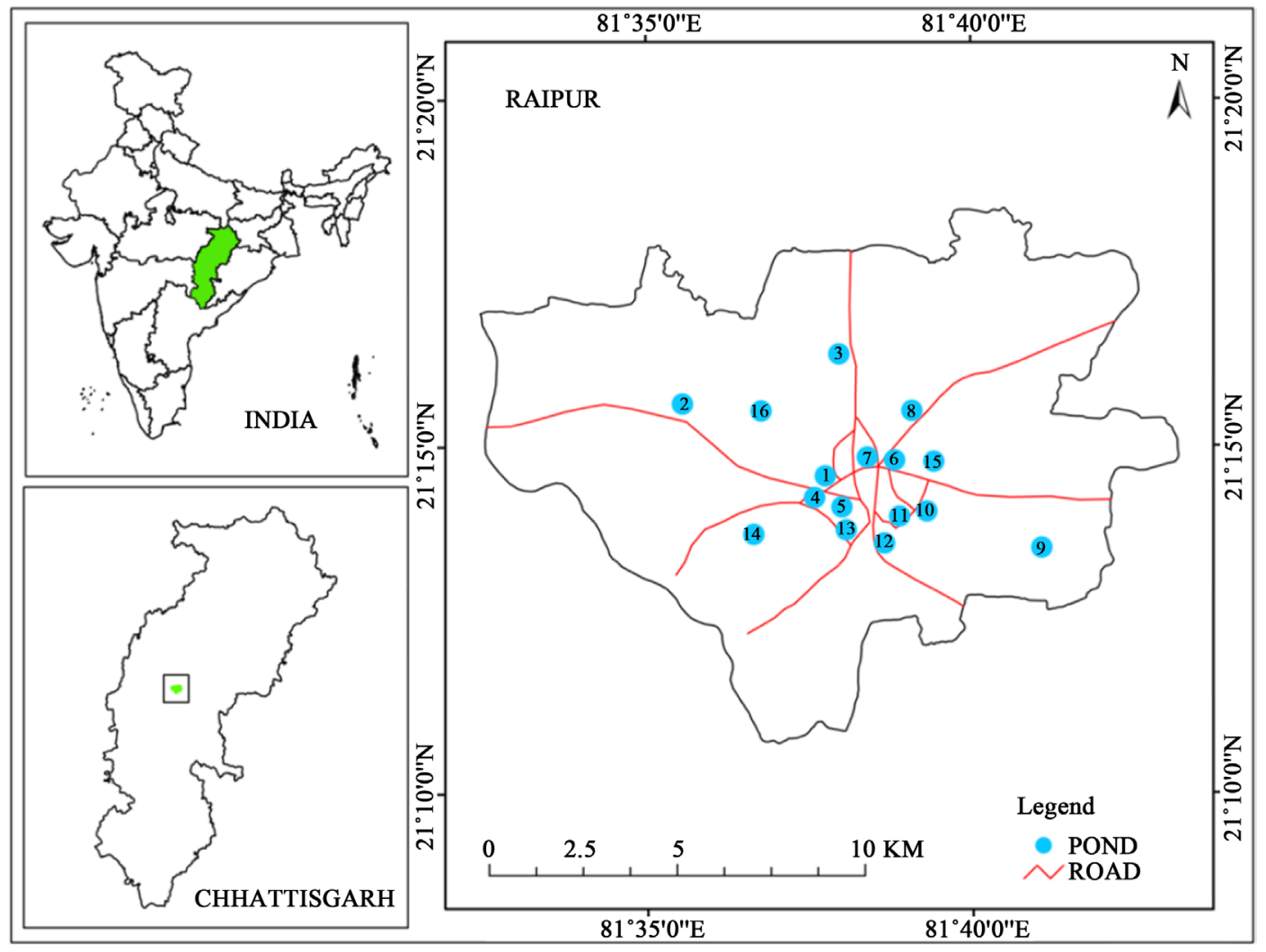

Figure 1. Representation of pond location in Raipur city, Chhattisgarh, India. 
where, all ions are expressed in meq/L.

The indicative microbes i.e. total coliforms (TC), fecal coliforms (FC), Pseudomonas aeruginosa, yeast and fungi were determined by the plate method prescribed by Rakiro Biotech System Pvt. Ltd [29]. The bactaslyde is a presterilized slide coated with specially developed media of lactose and indicator. The slide no. BS-101, BS-102 and BS-103 were used for detection of E. coli + TC, Pseudomonas + TC and yeast-fungi + TC, respectively. The slide was plunged into the test liquid vertically for 20 - $25 \mathrm{sec}$. The excess water of slide was removed by shaking, and incubated for $24 \mathrm{hrs}$ at $37^{\circ} \mathrm{C}$. The grown colonies of the slide was compared with the standard chart. The Salmonella bacteria in the water was detected by the pouch pack method [29]. The content (10 g) of two pouches (i.e. containing organics and sulfite material)were added into a 150-mL sterilized bottle filled with $100 \mathrm{~mL}$ of contaminated water, and incubatted for $24 \mathrm{hrs}$ at $37^{\circ} \mathrm{C}$. The presence of Salmonella species was confirmed by changing of light blue color of the solution into dark black due to reduction of sulfite into sulfide.

\section{Results and Discussion}

\subsection{Physical Characteristics}

The physical characteristic of 16 ponds is summarized in Table 1 . Among them, three ponds are in larger size, ranging in order of $1-3 \times 10^{5} \mathrm{~m}^{2}$. All ponds are eutrophied and coloured due to algal blooms. The $\mathrm{pH}$ and $\mathrm{T}$ values of pond water $(n=16)$ was varied from $6.5-8.2$ and $29.6^{\circ} \mathrm{C}-31.3^{\circ} \mathrm{C}$ with mean value of $7.0 \pm 0.2$ and 30.4 $\pm 0.2^{\circ} \mathrm{C}$, respectively. The water of all ponds was found to be neutral with high value of TH, TA and TDS, ranging $(\mathrm{n}=16)$ from $140-450,232-546$ and $1288-2475 \mathrm{mg} / \mathrm{L}$ with mean value of $280 \pm 45,391 \pm 34$ and $1659 \pm 164$ $\mathrm{mg} / \mathrm{L}$, respectively. The DO, RP, EC values $(\mathrm{n}=16)$ were ranged from $6.1-8.3 \mathrm{mg} / \mathrm{L}, 90$ - $195 \mathrm{mV}, 453$ - 1225 $\mu \mathrm{S} / \mathrm{cm}$ with mean value of $7.2 \pm 0.3,145 \pm 15 \mathrm{mV}$ and $800 \pm 124 \mu \mathrm{S} / \mathrm{cm}$, respectively. The DO value of all pond water was found above the recommended value of $4.0 \mathrm{mg} / \mathrm{L}$. The DO value in the summer (May-June) was reduced to the recommended value due to higher water temperature $\left(40^{\circ} \mathrm{C}\right)$. However, RP value was found to be several folds lower than recommended value of $650 \mathrm{mV}$, may be due to excessive organics load in the water.

Table 1. Physical characteristics of pond and pond water.

\begin{tabular}{ccccccccccc}
\hline S. No. & Location & Area, ${ }^{2}$ & $\mathrm{pH}$ & $\mathrm{EC}, \mu \mathrm{S} / \mathrm{cm}$ & $\mathrm{T},{ }^{\circ} \mathrm{C}$ & $\mathrm{RP}, \mathrm{mV}$ & $\mathrm{DO}, \mathrm{mg} / \mathrm{L}$ & $\mathrm{TDS} \mathrm{mg} / \mathrm{L}$ & $\mathrm{TH}, \mathrm{mg} / \mathrm{L}$ & $\mathrm{TA} \mathrm{mg} / \mathrm{L}$ \\
\hline P1 & Telibandha & $1.0 \times 10^{5}$ & 7.6 & 589 & 30.1 & 187 & 8.1 & 1323 & 150 & 380 \\
P2 & Budhatalab & $3.0 \times 10^{5}$ & 7.2 & 623 & 30.4 & 180 & 7.8 & 1934 & 200 & 346 \\
P3 & Tikarapara & $1.6 \times 10^{5}$ & 6.6 & 1115 & 30.6 & 132 & 7.6 & 1567 & 140 & 402 \\
P4 & Kankalipara & $1 \times 10^{4}$ & 7.1 & 771 & 29.8 & 195 & 8.0 & 1460 & 190 & 360 \\
P5 & Gudhiyari & $1 \times 10^{4}$ & 6.8 & 1225 & 31.3 & 167 & 7.5 & 2012 & 360 & 546 \\
P6 & Dudhadhari & $1 \times 10^{4}$ & 7.0 & 727 & 29.6 & 162 & 7.0 & 1340 & 320 & 326 \\
P7 & Rajatalab & $5 \times 10^{4}$ & 7.1 & 872 & 30.9 & 129 & 6.7 & 1913 & 370 & 372 \\
P8 & Aamapara & $3 \times 10^{4}$ & 8.2 & 960 & 30.1 & 118 & 7.2 & 1726 & 280 & 468 \\
P9 & Awanti Vihar & $1 \times 10^{4}$ & 7.1 & 474 & 30.8 & 107 & 6.8 & 2475 & 450 & 442 \\
P10 & Amlidih & $1 \times 10^{4}$ & 6.5 & 1149 & 30.2 & 90 & 7.4 & 1879 & 330 & 380 \\
P11 & Katoratalab & $1 \times 10^{4}$ & 6.7 & 630 & 31.1 & 114 & 6.1 & 1633 & 360 & 424 \\
P12 & Sonjharapara & $5 \times 10^{4}$ & 6.9 & 610 & 30.5 & 147 & 7.0 & 1504 & 250 & 436 \\
P13 & Mathpara & $1 \times 10^{4}$ & 7.0 & 870 & 30.0 & 131 & 6.3 & 1323 & 200 & 408 \\
P14 & P. Colony & $2 \times 10^{4}$ & 6.8 & 608 & 29.7 & 151 & 8.3 & 1400 & 350 & 340 \\
P15 & Rohinipuram & $1 \times 10^{4}$ & 7.0 & 453 & 30.4 & 160 & 6.8 & 1320 & 200 & 388 \\
P 16 & Kota & $2 \times 10^{4}$ & 7.1 & 1128 & 30.2 & 152 & 7.3 & 1288 & 330 & 232 \\
\hline
\end{tabular}

$\mathrm{P}=$ Professor. 


\subsection{Chemical and Microbe Characteristics}

The chemical characteristics of the pond water are shown in Table 2. The concentration of $\mathrm{F}^{-}, \mathrm{Cl}^{-}, \mathrm{NO}_{3}^{-}, \mathrm{SO}_{4}^{2-}$, $\mathrm{NH}_{4}^{+}, \mathrm{Na}^{+}, \mathrm{K}^{+}, \mathrm{Mg}^{2+}, \mathrm{Ca}^{2+}$, Fe and SLS was ranged $(\mathrm{n}=16)$ from $0.9-1.7,12-97,13-64,13-152,5-23,33-$ $177,8-83,6-24,22-64,0.33-1.14$ and $7-27 \mathrm{mg} / \mathrm{L}$ with mean value of $1.3 \pm 0.1,33 \pm 12,26 \pm 7,49 \pm 19,8 \pm$ $2,112 \pm 18,39 \pm 10,15 \pm 2,42 \pm 5,0.51 \pm 0.11$ and $17 \pm 3 \mathrm{mg} / \mathrm{L}$, respectively. Among16 pond investigated, the water of Awanti Vihar pond was found to be the most polluted due to mixing of sewage waste, Figure 2. Thecontaminants in the pond water of Raipur city was found to occur in the following decreasing sequence: $\mathrm{Na}^{+}<$ $\mathrm{SO}_{4}^{2-}<\mathrm{Ca}^{2+}<\mathrm{K}^{+}<\mathrm{Cl}^{-}<\mathrm{NO}_{3}^{-}<\mathrm{SLS}<\mathrm{Mg}^{2+}<\mathrm{NH}_{4}^{+}<\mathrm{F}^{-}<\mathrm{Fe}$.

The chromatograms of indicative bacteria (i.e. total coliform, E. coli and Pseudomonas, yeast and fungi) are shown in Figure 3, Figure 4. Their extreme concentrations were observed in all pond water reservoirs, ranging from $10^{2}-10^{7}$ count $/ \mathrm{mL}$ in Table 3. The positive test for Salmonella bacteria was marked for all water reservoirs in Figure 5.

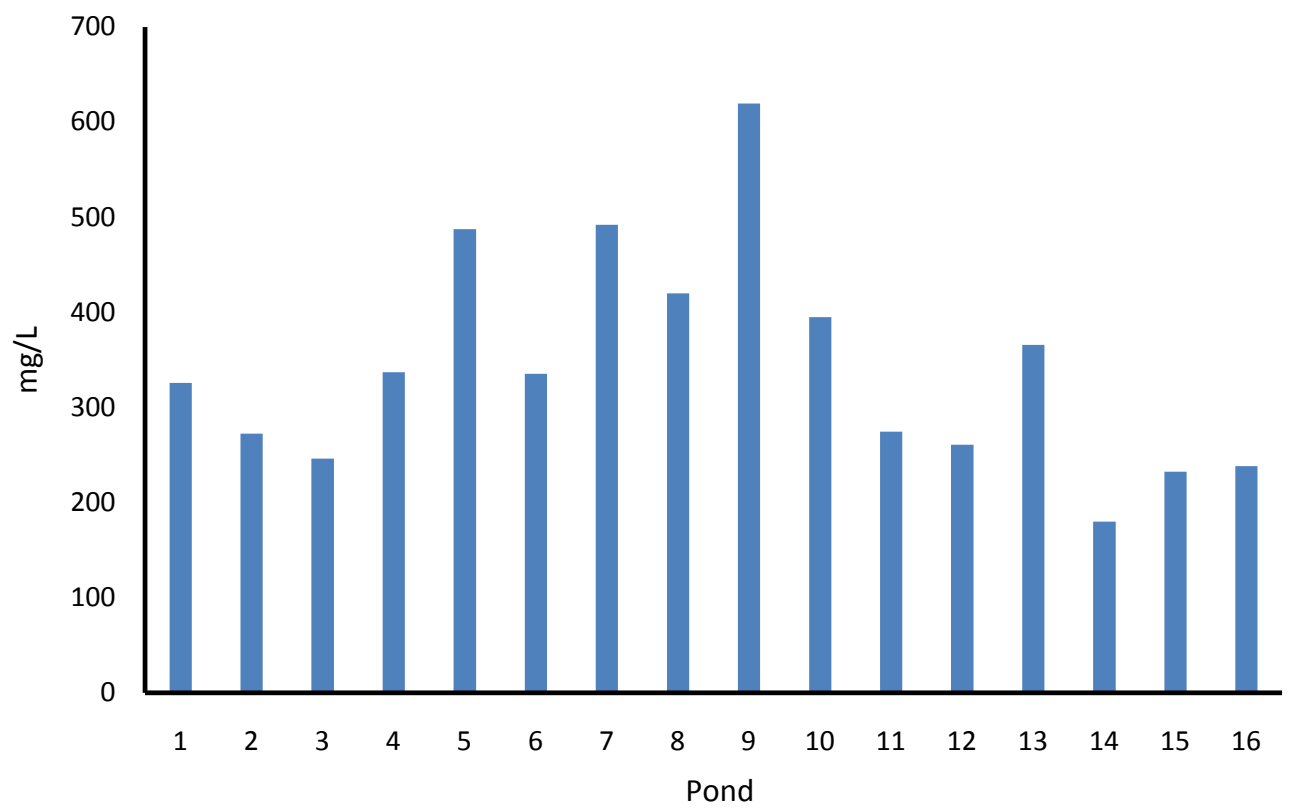

Figure 2. Spatial variation of sum of total concentration of 11 species i.e. ions, Fe and SLS.

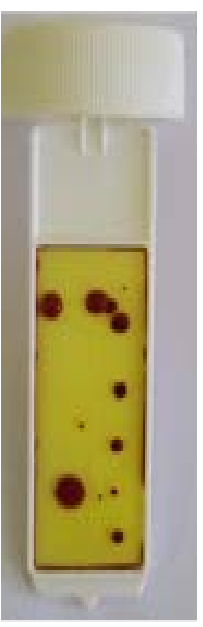

(a)

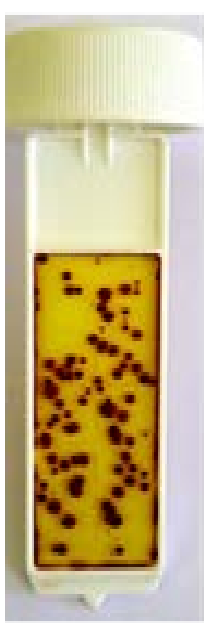

(b)

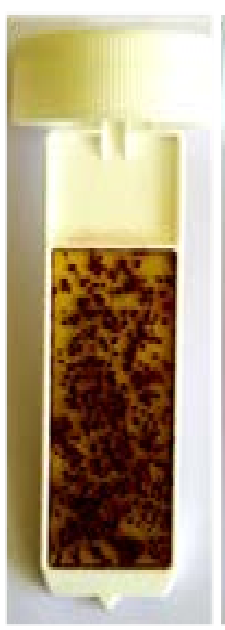

(c)

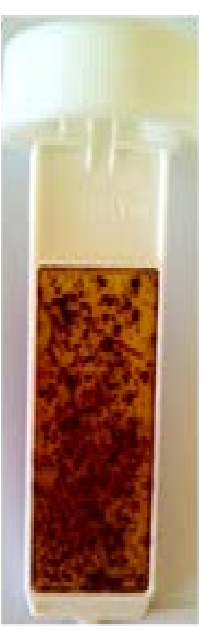

(d)

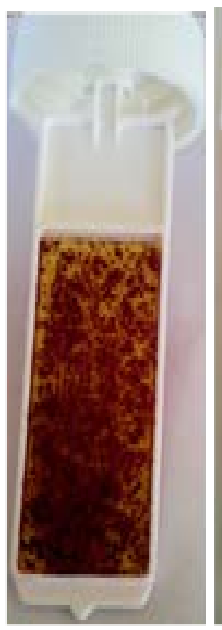

(e)

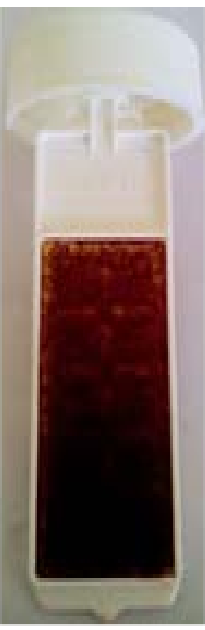

(f)

Figure 3. Representation of various chromatograms of E Coli + TC (Total coli). A, B, C, D, E and F $=1 \times 10^{2}, 1$ $\times 10^{3}, 1 \times 10^{4}, 1 \times 10^{5}, 1 \times 10^{6}$, and $1 \times 10^{7}$ count $/ \mathrm{mL}$, respectively. 
Table 2. Chemical characteristics of pond water, mg/L.

\begin{tabular}{cccccccccccc}
\hline S. No. & $\mathrm{F}^{-}$ & $\mathrm{Cl}^{-}$ & $\mathrm{SO}_{4}^{2-}$ & $\mathrm{NO}_{3}^{-}$ & $\mathrm{NH}_{4}^{+}$ & $\mathrm{Na}^{+}$ & $\mathrm{K}^{+}$ & $\mathrm{Mg}^{2+}$ & $\mathrm{Ca}^{2+}$ & $\mathrm{Fe}$ & $\mathrm{SLS}$ \\
\hline P1 & 1.3 & 32 & 50 & 27 & 6.1 & 106 & 33 & 15 & 38 & 0.43 & 17 \\
P2 & 1.0 & 21 & 30 & 19 & 6.2 & 91 & 34 & 12 & 44 & 0.37 & 14 \\
P3 & 1.6 & 15 & 18 & 13 & 6.2 & 100 & 31 & 6 & 38 & 0.37 & 17 \\
P4 & 1.3 & 38 & 60 & 31 & 6.3 & 96 & 36 & 13 & 40 & 0.53 & 15 \\
P5 & 1.0 & 44 & 68 & 35 & 8.0 & 173 & 70 & 14 & 48 & 0.50 & 26 \\
P6 & 1.0 & 15 & 21 & 17 & 9.1 & 116 & 83 & 14 & 40 & 0.42 & 19 \\
P7 & 1.6 & 78 & 122 & 56 & 13 & 105 & 37 & 17 & 46 & 0.39 & 16 \\
P8 & 1.4 & 31 & 47 & 21 & 7.4 & 177 & 66 & 20 & 22 & 0.34 & 27 \\
P9 & 1.7 & 97 & 152 & 64 & 6.3 & 144 & 58 & 24 & 50 & 0.51 & 22 \\
P10 & 0.8 & 41 & 62 & 29 & 23 & 126 & 35 & 16 & 40 & 0.91 & 21 \\
P11 & 1.1 & 16 & 23 & 14 & 7.1 & 93 & 27 & 15 & 64 & 0.37 & 14 \\
P12 & 1.0 & 17 & 24 & 15 & 5.4 & 102 & 37 & 12 & 30 & 1.14 & 16 \\
P13 & 1.6 & 29 & 42 & 18 & 6.5 & 156 & 32 & 12 & 44 & 0.75 & 24 \\
P14 & 1.3 & 21 & 25 & 17 & 9.0 & 33 & 8.0 & 18 & 40 & 0.51 & 7 \\
P15 & 1.6 & 24 & 32 & 19 & 6.6 & 75 & 15 & 12 & 36 & 0.33 & 11 \\
P16 & 1.3 & 12 & 13 & 13 & 6.4 & 91 & 15 & 15 & 58 & 0.35 & 13 \\
\hline
\end{tabular}

Table 3. Microbe contamination of pond water.

\begin{tabular}{|c|c|c|c|c|}
\hline S. No. & E. coli + TC & Pseud. + TC & $\mathrm{Y}+\mathrm{F}+\mathrm{TC}$ & Salmonella \\
\hline P1 & $10^{4}$ & $10^{2}$ & $10^{4}$ & Positive \\
\hline P2 & $10^{3}$ & $10^{2}$ & $10^{4}$ & Positive \\
\hline P3 & $10^{4}$ & $10^{2}$ & $10^{3}$ & Positive \\
\hline P4 & $10^{3}$ & $10^{2}$ & $10^{4}$ & Positive \\
\hline P5 & $10^{7}$ & $10^{4}$ & $10^{5}$ & Positive \\
\hline P6 & $10^{4}$ & $10^{2}$ & $10^{4}$ & Positive \\
\hline P7 & $10^{4}$ & $10^{2}$ & $10^{4}$ & Positive \\
\hline P8 & $10^{5}$ & $10^{3}$ & $10^{4}$ & Positive \\
\hline P9 & $10^{4}$ & $10^{2}$ & $10^{4}$ & Positive \\
\hline $\mathrm{P} 10$ & $10^{7}$ & $10^{5}$ & $10^{4}$ & Positive \\
\hline P11 & $10^{5}$ & $10^{6}$ & $10^{6}$ & Positive \\
\hline $\mathrm{P} 12$ & $10^{4}$ & $10^{2}$ & $10^{3}$ & Positive \\
\hline P13 & $10^{5}$ & $10^{3}$ & $10^{5}$ & Positive \\
\hline P14 & $10^{4}$ & $10^{2}$ & $10^{3}$ & Positive \\
\hline P15 & $10^{5}$ & $10^{3}$ & $10^{5}$ & Positive \\
\hline P16 & $10^{5}$ & $10^{3}$ & $10^{4}$ & Positive \\
\hline
\end{tabular}




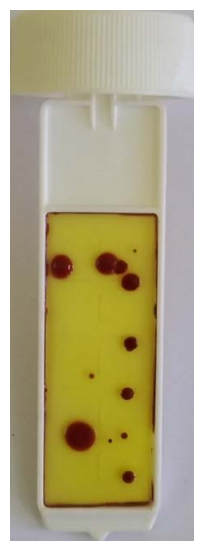

(a)

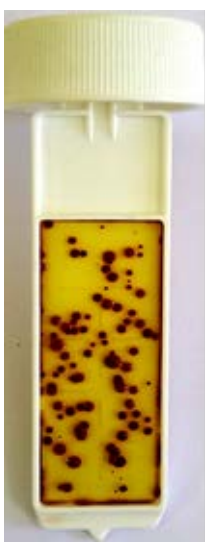

(b)

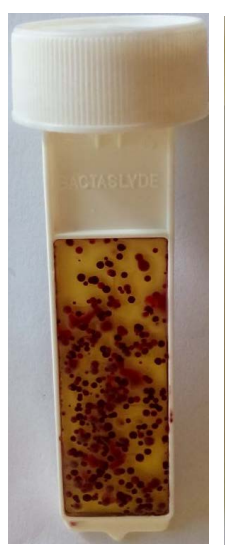

(c)

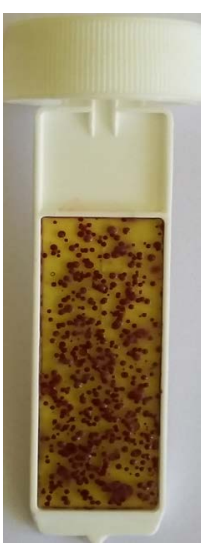

(d)

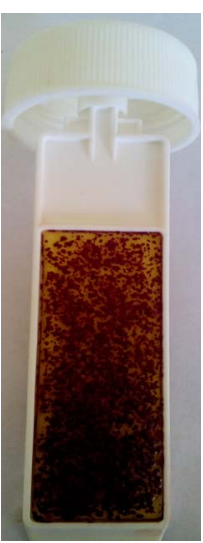

(e)

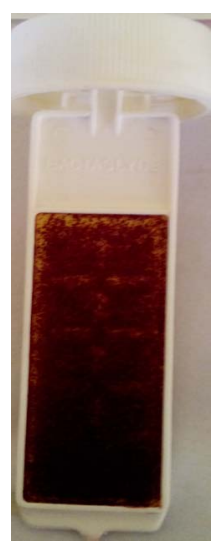

(f)

Figure 4. Representation of various chromatogram of PM (Pseudomonas) + TC. A, B, C, D, E and F $=1 \times 10^{2}, 1$ $\times 10^{3}, 1 \times 10^{4}, 1 \times 10^{5}, 1 \times 10^{6}$, and $1 \times 10^{7}$ count $/ \mathrm{mL}$, respectively.

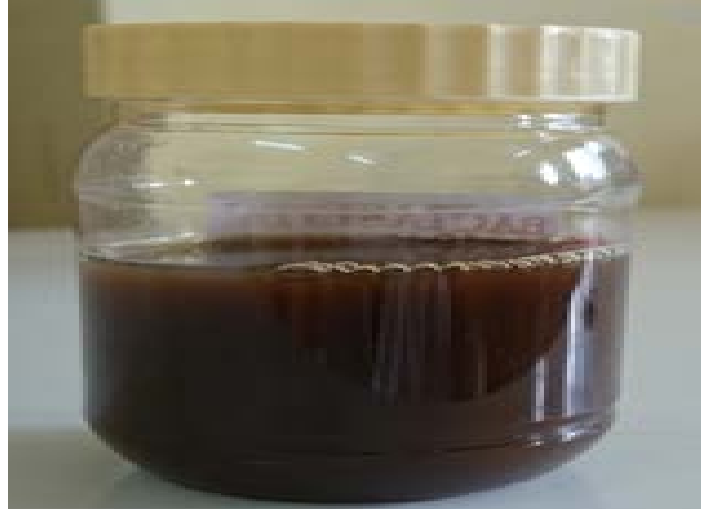

(a)

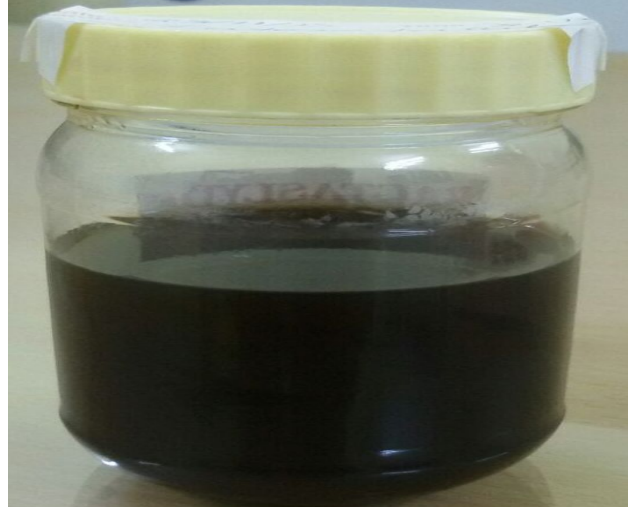

(b)

Figure 5. Test scenario of Salmonella. (a) = Reagent blank; (b) = Positive symptoms for Salmonella.

\subsection{Water Quality Assessment}

The SH and SAR values of pond water were ranged from 31\% - 77\% and $1.7-11.3$ with mean value of $62 \% \pm 5 \%$ and $6.5 \pm 1.1$, respectively, indicating sodic nature of the water. The value of Fe, SLS, TA and TDS content of all pond waters were found above than recommended value of 0.3, 1.0, 120 and $500 \mathrm{mg} / \mathrm{L}$, respectively [30] [31]. All pond waters were found to be contaminated with TB beyond 100 count/100 mL. The pond water is found to be unsuitable for drinking purpose due to microbe and surfactant contamination at hazardous levels.

The contaminated pond water affect the water quality of the shallow tube well water lie in the nearby area. The SLS and microbe contents in the shallow tube well $(\mathrm{n}=16)$ were ranged from $3.2-5.1 \mathrm{mg} / \mathrm{L}$ and $1 \times 10^{3}$ count/mL, respectively. The surfactant and microbial contamination levels in the water of the studied area was found to be comparable to the contents reported in the water of other region of the country and world [10]-[25].

\subsection{Sources}

The correlation matrix of the water parameters is summarized in Table 4. Among them, $\mathrm{Na}^{+}$and $\mathrm{K}^{+}$contents were found to be correlated well with the SLS, indicating origin from the $\mathrm{CH}_{3}\left(\mathrm{CH}_{2}\right)_{11} \mathrm{OSO}_{3}^{-} \mathrm{Na}^{+}$. A good correlation among three species i.e. $\mathrm{NO}_{3}^{-}, \mathrm{SO}_{4}^{2-}$ and $\mathrm{Mg}^{2+}$ was observed, showing similarity in their origins. The value of $\left[\mathrm{Na}^{+}\right] /\left[\mathrm{Cl}^{-}\right]$was found to be ranged from $2-13$ with mean value of $7 \pm 2$. It means that $\mathrm{Na}^{+}$was found to be originated mainly from the anthropogenic sources i.e. use of sodium lauryl sulphate as soap and detergent. The main inventories of the SLS and microbes contamination of the pond water are bathing, cloth washing and mixing of sewage waste and runoff water. 
Table 4. Correlation matrix of ions and SLS.

\begin{tabular}{|c|c|c|c|c|c|c|c|c|c|c|c|}
\hline & $\mathrm{F}^{-}$ & $\mathrm{Cl}^{-}$ & $\mathrm{SO}_{4}^{2-}$ & $\mathrm{NO}_{3}^{-}$ & $\mathrm{NH}_{4}^{+}$ & $\mathrm{Na}^{+}$ & $\mathrm{K}^{+}$ & $\mathrm{Mg}^{2+}$ & $\mathrm{Ca}^{2+}$ & $\mathrm{Fe}$ & SLS \\
\hline $\mathrm{F}^{-}$ & 1 & & & & & & & & & & \\
\hline $\mathrm{Cl}^{-}$ & 0.40 & 1 & & & & & & & & & \\
\hline $\mathrm{SO}_{4}^{2-}$ & 0.38 & 1.00 & 1 & & & & & & & & \\
\hline $\mathrm{NO}_{3}^{-}$ & 0.33 & 0.99 & 0.99 & 1 & & & & & & & \\
\hline $\mathrm{NH}_{4}^{+}$ & -0.39 & 0.24 & 0.23 & 0.23 & 1 & & & & & & \\
\hline $\mathrm{Na}^{+}$ & 0.04 & 0.36 & 0.38 & 0.32 & 0.06 & 1 & & & & & \\
\hline $\mathrm{K}^{+}$ & -0.23 & 0.29 & 0.32 & 0.32 & 0.04 & 0.73 & 1 & & & & \\
\hline $\mathrm{Mg}^{2+}$ & 0.19 & 0.64 & 0.64 & 0.61 & 0.20 & 0.23 & 0.26 & 1 & & & \\
\hline $\mathrm{Ca}^{2+}$ & -0.02 & 0.12 & 0.11 & 0.14 & -0.01 & -0.15 & -0.22 & 0.09 & 1 & & \\
\hline $\mathrm{Fe}$ & -0.28 & 0.00 & 0.01 & -0.03 & 0.30 & 0.13 & -0.01 & -0.07 & -0.26 & 1 & \\
\hline SLS & 0.01 & 0.35 & 0.37 & 0.30 & 0.13 & 0.99 & 0.75 & 0.22 & -0.21 & 0.18 & 1 \\
\hline
\end{tabular}

\section{Conclusion}

The pond water is polluted tremendously with the surfactant and microbe mainly due to anthropogenic activities i.e. bathing, washing and mixing of the runoff and municipal waste. The surfactant contamination of the pond imparts the water to be sodic in nature. In some ponds $(\approx 25 \%)$, the $\mathrm{F}^{-}$content is found to be above the recommended value of $1.5 \mathrm{mg} / \mathrm{L}$. All ponds are eutrophied with green algal blooms due to the nutrient over loadings.

\section{Acknowledgements}

We are thankful to our University for special equipment grant aid to the Environmental Science Department.

\section{References}

[1] Pandey, P.K., Kass, P.H., Soupir, M.L., Biswas, S. and Singh, V.P. (2014) Contamination of Water Resources by Pathogenic Bacteria. ABA Express, 4, 51. http://dx.doi.org/10.1186/s13568-014-0051-x

[2] Skordas, E., Kelepertzis, E., Kosmidis, D., Panagiotaki, P. and Vafidis, D. (2015) Assessment of Nutrients and Heavy Metals in the Surface Sediments of the Artificially Lake Water Reservoir Karla, Thessaly, Greece. Environmental Earth Sciences, 73, 4483-4493. http://dx.doi.org/10.1007/s12665-014-3736-1

[3] Klecka, G., Persoon, C. and Currie, R. (2010) Chemicals of Emerging Concern in the Great Lakes Basin: An Analysis of Environmental Exposures. Reviews of Environmental Contamination and Toxicology, 207, 1-93. http://dx.doi.org/10.1007/978-1-4419-6406-9 1

[4] Ashbolt, N.J. (2004) Microbial Contamination of Drinking Water and Disease Outcomes in Developing Regions. Toxicology, 198, 229-238. http://dx.doi.org/10.1016/j.tox.2004.01.030

[5] Sharma, S., Sachdeva, P. and Virdi, J.S. (2003) Emerging Water-Borne Pathogens. Applied Microbiology and Biotechnology, 61, 424-428. http://dx.doi.org/10.1007/s00253-003-1302-y

[6] Zoller, U. (2004) Handbook of Detergents: Part B Environmental Impact. Marcel Dekker, New York, 838.

[7] Ostroumov, S.A. (2005) Biological Effects of Surfactants. CRC Press. https://www.crcpress.com/Biological-Effects-of-Surfactants/Ostroumov/9780849325267

[8] Seth, R., Singh, P., Mohan, M., Singh, R. and Aswal, R.S. (2013) Monitoring of Phenolic Compounds and Surfactants in Water of Ganga Canal, Haridwar (India). Applied Water Science, 3, 717-720. http://dx.doi.org/10.1007/s13201-013-0116-Z

[9] Yang, G., Fan, M. and Zhang, G. (2014) Emerging Contaminants in Surface Waters in China. Environmental Research Letters, 9, 13.

[10] Pastewski, S. and Mędrzycka, K. (2003) Monitoring Surfactant Concentrations in Surface Waters in Tricity Agglomeration. Polish Journal of Environmental Studies, 12, 643-646. http://www.pjoes.com/pdf/12.5/643-646.pdf 
[11] Petrovic, M., Fernández-Alba, A.R., Borrull, F., Marce, R.M., Mazo, E.G. and Barceló, D. (2002) Occurrence and Distribution of Nonionic Surfactants, Their Degradation Products, and Linear Alkylbenzene Sulfonates in Coastal Waters and Sediments in Spain. Environmental Toxicology and Chemistry, 21, 37-46. http://dx.doi.org/10.1002/etc.5620210106

[12] Miura, K., Nishiyama, N. and Yamamoto, A. (2008) Aquatic Environmental Monitoring of Detergent Surfactants. Journal of Oleo Science, 57, 161-170. http://dx.doi.org/10.5650/jos.57.161

[13] Eichhorn, P., Flavier, M.E., Paje, M.L. and Kneppe, T.P. (2001) Occurrence and Fate of Linear and Branched Akylbenzene Sulfonates and Their Metabolites in Surface Waters in the Philippines. Science of the Total Environment, 269, 75-85. http://dx.doi.org/10.1016/S0048-9697(00)00825-1

[14] Sarrazin, L., Diana, C., Wafo, E. and Rebouillon, P. (2003) Level of Linear Alkylbenzene Sulfonates (LAS) in Sediments of the Berre Lagoon (France). International Journal of Environnemental Studies, 60, 229-240. http://dx.doi.org/10.1080/0020723022000026293

[15] Zoller, U. and Hushan, M. (2001) The Nonionic Surfactant Pollution Profile of Israel Mediterranean Sea Coastal Water. Water Science and Technology, 43, 245-250.

[16] Zoller, U. (2006) Estuarine and Coastal Zone Marine Pollution by the Nonionic Alkylphenol Ethoxylates Endocrine Disrupters: Is There a Potential Ecotoxicological Problem? Environment International, 32, 269-272. http://dx.doi.org/10.1016/j.envint.2005.08.023

[17] Mukhopadhyay, C., Vishwanath, S., Eshwara, V.K., Shankaranarayana, S.A. and Sagir, A. (2012) Microbial Quality of Well Water from Rural and Urban Households in Karnataka, India: A Cross-Sectional Study. Journal of Infection and Public Health, 5, 257-262. http://dx.doi.org/10.1016/j.jiph.2012.03.004

[18] Singh, U.S., Meena, S.S., Soni, N.K., Pradhan, S., Bhawra, H., Bhalla, S.R. and Kumar, S. (2005) Surveillance of Bacteriological Quality of Natural Water Resources in Rural Areas around Kasauli Town, Distt Solan, Himachal Pradesh. The Journal of Communicable Diseases, 37, 289-295.

[19] Antai, S.P. (1987) Incidence of Staphylococcus Aureus, Coliforms and Antibiotic-Resistant Strains of Escherichia coli in Rural Water Supplies in Port Harcourt. The Journal of Applied Bacteriology, 62, 371-375. http://dx.doi.org/10.1111/j.1365-2672.1987.tb04933.x

[20] Suthar, S., Chhimpa, V. and Singh, S. (2009) Bacterial Contamination in Drinking Water: A Case Study in Rural Areas of Northern Rajasthan, India. Environmental Monitoring and Assessment, 159, 43-50. http://dx.doi.org/10.1007/s10661-008-0611-0

[21] Anand, C., Akolkar, P. and Chakrabarti, R. (2006) Bacteriological Water Quality Status of River Yamuna in Delhi. Journal of Environmental Biology, 27, 97-101.

[22] Krishnan, R.R., Dharmaraj, K. and Ranjitha Kumari, B.D. (2007) A Comparative Study on the Physicochemical and Bacterial Analysis of Drinking, Borewell and Sewage Water in the Three Different Places of Sivakasi. Journal of Environmental Biology, 28, 105-108. http://jeb.co.in/journal issues/200701 jan07/paper 18.pdf

[23] Sayed Rizwan, A. and Gupta, S.G. (2011) Bacterial Contamination of Surface Water in and around Beed District, Maharashtra, India. Journal of Microbial and Biochemical Technology, 3, 88-91. http://dx.doi.org/10.4172/1948-5948.1000057

[24] Gogoi, P. and Sharma, D. (2013) Microbial Contamination of Community Pond Water in Dibrugarh District of Assam. Current World Environment, 8, 85-91. http://dx.doi.org/10.12944/CWE.8.1.09

[25] Suthar, S., Chhimpa, V. and Singh, S. (2009) Bacterial Contamination in Drinking Water: A Case Study in Rural Areas of Northern Rajasthan, India. Environmental Monitoring and Assessment, 159, 43-50. http://dx.doi.org/10.1007/s10661-008-0611-0

[26] APHA (2005) Standard Methods for the Examination of Water and Wastewater. 21st Edition, APHA, AWWA and WEF, Washington DC.

[27] Nollet Leo, M.L. and De Gelder Leen, S.P. (2007) Handbook of Water Analysis, 2nd Edition, CRC Press, Boca Raton, 784 p. https://www.crcpress.com/Handbook-of-Water-Analysis-Second-Edition/Nollet-De-Gelder/9780849370335

[28] Patel, R. and Patel, K.S. (1998) Flow Injection Determination of Anionic Surfactants with Cationic Dyes in Water Bodies of Central India. Analyst, 123, 1691-1695. http://dx.doi.org/10.1039/a802945h

[29] Rakiro Biotech System Pvt. Ltd, Bactaslyde Microbe Detection Device. http://rakiro.net/bactaslyde.html

[30] BIS (2003) Indian Standard Drinking Water Specifications (IS 10500:1991). Edition 2.2 (2003-2009), Bureau of Indian Standard, New Delhi.

[31] WHO (2011) Guidelines for Drinking Water Quality. 4th Edition, World Health Organization, Geneva. http://apps.who.int/iris/bitstream/10665/44584/1/9789241548151_eng.pdf 